\title{
Effect of selected planting dates on root- knot nematodes population and productivity of sugarbeet variety, Pleno
}

\author{
Rady, G. H. H.; Gaabob, I. A.; Gohar, I. M. A.; Eliwa, H. M. and Sabra, T. F. Y.
}

Corresponding author: tamer.fathy@ savola.com

\begin{abstract}
The effect of three planting dates (August 25, September and October) on infectivity of root- knot nematode species and productivity of sugar beet var. Pleno was evaluated. The results indicated that the $1^{\text {st }}$ planting date showed the highest values of nematode infection parameters (i.e. numbers of galls, eggmasses, development stages root system ${ }^{-1}$, juveniles in soil and final population as well as reproduction factor) followed by $2^{\text {nd }}$ planting date. However, the $3^{\text {rd }}$ planting date achieved the lowest values of those nematode parameters. In addition, the data revealed that the $1^{\text {st }}$ planting date obtained only the highest values for sucrose and purity percentages. On the other hand, the $3^{\text {rd }}$ planting date recorded the highest values of roots, top, biological and sugar yields (tons fed $^{-1}$ ). Therefore, the $3^{\text {rd }}$ planting date (during October) was the most effective date against concerned species of rootknot nematodes on naturally infested sugar beet grown in sandy soil using drip irrigation system.
\end{abstract}

Key words: planting dates, root- knot nematodes, control sugar beet productivity, Pleno.

\section{Introduction}

Sugar beet represents the corner stone to reduce the gap between production and consumption of sugar in Egypt, which estimates as 0.8 million tons of sugar in 2014/ 2015. Since its introduction to the Egyptian farming system in 1982, the beet cultivated area increased from 16943 to 480000 feddans in 2014/ 15 season. The sugar produced from beet also increased from $2.5 \%$ of the total sugar produced in 1982 to $56 \%$ of the total sugar produced in 2014/ 15 season.

In Egypt, the west Nubaryia region is growing sugar beet to secure optimal processing two or more parasitic nematodes are known to cause serious problems to beet fields at West Nubaryia region. to secure optimal processing amount of beet sugar factories (Alexandria, Nil and Nubaryia) in this area. Root- knot nematodes species, Meloidogyne incognita and $M$. javanica have been reported as major nematode pests of sugar beet in Egypt (Ibrahim, 1982; Oteifa and El- Gindi, 1982; Abd-El- Massih, 1985; Maareg et al., 1988 a\& b, 1998. 2005 and 2009; Ismail et al, 1996; Gohar, 2003; Gohar and Maareg, 2005 and Gohar et al 2012). The $M$. incognita and M. javanica are attacking all sugar beet varieties in newly reclaimed soils. Total varieties failures frequently occur when varieties are planted in areas with high nematode population levels (Maareg et al, 1998, 2005; Maareg and Hassanen, 1999; Gohar, 2003 and Gohar and Maareg, 2005). The average loss in sugar beet yield in Egypt due to $M$. incognita in different areas and at West Nubaryia was estimated to be $>50 \%$ in sugar yield and $>68 \%$ in roots yield for susceptible varieties (Gohar and Maareg, 2005).

Plant parasitic nematodes need to be managed to maintain the quality and abundance of food and fiber produced by growers around the world (Pal and
Mcspadden, 2006). Eliminating nematodes is not possible; the goal is to manage their population and reduce their numbers below the damaging levels. Conventional management methods used include planting resistant crop varieties, rotating crops, land fallowing, and flooding, plugging, rouging, incorporating soil amendments, time of planting, nematode suppressive plants, bio control practices and applying pesticides. In some cases, soil solarization also may be practical.

Pesticides may case heavy environmental pollution, for example water contamination and toxicity to animals and humans. These negative effects on the environmental led to restrictions in nematicide use and are nowadays less widely applied than in the past, The use of synthetic pesticides for plant protection against agriculture pests during the last 50 years created many problems. Namely, pest resistance, environmental pollution and disturbance in natural balance. To overcome this problem many researchers all over the world are looking to discover new safe types of pest control agents Gaaboub 2005 and 2012.

Hence, this work was outlined to study the effect of selected planting dates as a management method of Meloidogyne species and improving of sugar beet productivity in naturally infested soil of Ahmed Badawy village at West Nubaryia region.

\section{Materials and Methods}

This work was carried out during 2012/ 13 and 2013/ 14 seasons at Ahmed Badawy village, West Nubaryia region, Al- Behera governorate, Egypt to study the effects of selected sowing dates (as agricultural method) on root- knot nematodes, Meliodogyne species, (as common species in this area) and the performance of sugarbeet variety, Pleno. The 
three planting dates used in this work were as follows: (i) the first date is August 25, the second date is September 25 and the third one is October 25.

The experimental fields were naturally infested with a mixture of the root-knot nematodes, $M$. incognita and $M$. javanica and was grown by sugarbeet for the last ten years. The soil type was sandy (89\% sand, $5 \%$ silt, $6 \%$ clay; $0.3 \%$ organic matter) with $\mathrm{pH}$ of 7.8 and $9.3 \% \quad \mathrm{CaCO}_{3}$.Drip irrigation system was applied in the experimental plots.

Each growing season experiment was laid out in a completely randomized block design. The plot was six rows wide by $7 \mathrm{~m}$ long, with $0.5 \mathrm{~m}$ row spacing. The preceding crop of the first and the second seasons was watermelon. Seeds of sugarbeet were sown at $20 \mathrm{~cm}$ between hills. Seedlings were thinned to one plant per hill at the four leaf stage. Nitrogen fertilization was added according to the recommendation of Sugar Crops Research Institute (SCRI). The rate of $100 \mathrm{Kg}$ of nitrogen per feddan in the form ammonium nitrate (33.5\%) was applied at two doses after thinning and one month later. Also phosphate fertilization was applied at the rate of $200 \mathrm{Kg}$ per feddan in the form calcium super phosphate $\left(15.5 \% \quad \mathrm{P}_{2} \mathrm{O}_{5}\right)$ during soil preparation. The other agricultural practices for growing sugarbeet were done as for newly reclaimed soils without pesticide application. Soil temperature was recoded at a depth of $25 \mathrm{~cm}$ for each plot at planting. (Table1)

Table 1. Average of soil temperature at first, second and third planting dates

\begin{tabular}{lccc}
\hline Seasons & $25-8$ & $25-9$ & $25-10$ \\
\hline $\mathbf{2 0 1 3 - 2 0 1 4}$ & $29.9^{\circ} \mathrm{c}$ & $21.3^{\circ} \mathrm{c}$ & $17.1^{\circ} \mathrm{c}$ \\
$\mathbf{2 0 1 4 - 2 0 1 5}$ & $29.3^{\circ} \mathrm{c}$ & $23.4^{\mathrm{o}} \mathrm{c}$ & $15.3^{\circ} \mathrm{c}$ \\
Average & $29.6^{\circ} \mathrm{c}$ & $22.4^{\circ} \mathrm{c}$ & $16.2^{\circ} \mathrm{c}$ \\
\hline
\end{tabular}

Nematode samples consisted of $10-15$ cores $(5 \mathrm{~cm}$ diameter $\times 25 \mathrm{~cm}$ deep) taken from the two center rows of each plot at planting and at harvesting dates to determine the initial and final root- knot nematodes population, respectively. The $10-15$ cores were mixed manually and a $250 \mathrm{~cm}^{3}$ subsample was collected for nematode analysis. Three replications were tested for each nematode parameter. The subsamples were wetsieved through nested 100, 200 and 325 mesh sieves. The material retained on the 325 mesh sieves was processed by baermann- pan technique Barker (1985). The extracted nematodes were dispersed in water in a gridded counting dish, identified and enumerated. All nematode counts from soil were standardized to 250 $\mathrm{cm}^{3}$ of soil. At harvest (210 days after planting), five root systems were taken at random from the two center rows of each plot and washed. The number of galls per root system was recorded. A 15 gram fresh weight subsample was randomly taken, and nematode juveniles were extracted using a Baermann- Pan technique. After 5 days, nematodes were counted and then standardized to the number per gram fresh weight of root. Other subsamples (15 gram fresh weight) were randomly taken, washed, stained with acid fuchsine in lactophenol, and stored for 24 hours. The number of nematode juveniles, females and eggmasses were counted and standardized to the numbers per gram fresh weight of root system. Three replications were tested for each nematode parameter. Reproduction factor was calculated as follows:

$$
\mathrm{RF}=\frac{\sum \text { Final nematodes in soil and roots }}{\text { Initial population }}
$$

Samples of roots were taken and submitted for analysis on the same harvesting day to beet reception laboratory in Alexandria Sugar Company to measure the following trails: sugar percentage according to De
Whalley (1964), purity\% and expected sugar yield per feddan.

From each plot, the outer two rows were considered as a belt, while plants of the $2^{\text {nd }}$ and $5^{\text {th }}$ rows were kept for determination of yield, yield components and quality. The other rows, $3^{r d}, 4^{\text {th }}$ were used for nematode parameters.

The determined trails or parameters during both growing seasons for each planting date experiment were as follows:

\section{I- Nematode parameters:}

1. Number of galls $(\mathrm{G})$ root system $^{-1}$.

2. Number of egg- masses (E.M) root system ${ }^{-1}$.

3. Number of development stages (D.S) root system $^{-1}$.

4. Number of juveniles $\left(\mathbf{J}_{2}\right)$ in soil.

5. Number of final population.

6. Reproduction factor (R.F).

II- Yield and yield components:

1. Root yield tons fad $^{-1}$

2. Top yield tons fad $^{-1}$

3. Biological yield tons fad $^{-1}$

4. Sugar yield tons fad $^{-1}$

III -Technological parameters:

1. Sucrose percentage.

2. Juice purity percentage.

\section{Statistical analysis:}

The obtained data of the two seasons and their combined analysis were calculated according to Mc Intosh, (1983). The treatment means were compared by using the least significant difference (L.S.D) test (Steel and Torrie, 1980) at 5\% level of significance. 


\section{Results and Discussion}

I- Effect of selected planting dates on of root- knot nematode parameters on sugar beet:

The reduction of root- knot nematode species parameters (number of galls, eggmasses and developmental stages root system ${ }^{-1}$, juveniles $\left(\mathbf{J}_{2}\right)$ in soil, and final population as well as reproduction factor) is the major purpose of this study. Differences among plant genetic, climatic parameters and reduction influences were selected.

The data in Table (2) showed the effect of three planting dates (25 ${ }^{\text {th }}$ August, September and October) on parameters of root- knot nematodes infection using sugar beet var. Pleno.

\section{I-1- Number of galls $(G)$ root system $^{-1}$ :}

The $2^{\text {nd }}$ planting date showed the highest $G$ root system $^{-1}(100.33)$ followed by the $3^{\text {rd }}$ planting date (97.33) and the $1^{\text {st }}$ one (74.17) root system $^{-1}$, respectively, with insignificant differences among them. The reduction percentage of $\mathrm{G}$ root system ${ }^{-1}$ than the $2^{\text {nd }}$ planting date was 26.07 and $2.99 \%$ for the $1^{\text {st }}$ and $3^{\text {rd }}$ planting date, respectively (Table 2 ).

I-2- Number of eggmasses (E.M) root system $^{-1}$ :

The E.M root system ${ }^{-1}$ decreased with delaying planting dates. Therefore, there were position correlation between planting dates and reduction of E.M root system ${ }^{-1}$. The first planting date significantly reduced the E.M. compared to the other two planting dates. The differences of E.M reduction root system ${ }^{-1}$ between the $1^{\text {st }}$ and the $2^{\text {nd }}$ planting date were $33.85 \%$ while was $35.29 \%$ when comparing the $1^{\text {st }}$ with the $3^{\text {rd }}$ one.

\section{I-3- Number of developmental stages (N.D.S) root system $^{-1}$ : \\ Data concerning the number of developmental stages (D.S) root system $^{-1}$ indicated that the $3^{\text {rd }}$ planting date was the best planting date to significantly reduce nematode parameters compared to the other two planting dates. The relative reduction percentage of D.S root system $^{-1}$ between the $1^{\text {st }}$ planting date and the $2^{\text {nd }}$ one was $13.46 \%$, while this reduction recorded $64.84 \%$ between the $1^{\text {st }}$ and the $3^{\text {rd }}$ one (Table, 2).}

\section{I-4- Number of juveniles $\left(J_{2}\right) 250 \mathrm{~cm}^{3} \mathrm{soil}^{-1}$ :}

The juvenile's population $\left(\mathrm{J}_{2}\right)$ in soil was significantly decreased with delaying planting dates. Therefore, position correlations were found between planting dates and juveniles reduction in soil. The relative reduction percentage of $\mathrm{J}_{2}$ between the $1^{\text {st }}$ and the $2^{\text {nd }}$ planting date were $64.25 \%$ and $78.21 \%$ with the $3^{\text {rd }}$ one.

Table 2. Effect of selected planting dates on population of root- knot nematodes on sugar beet variety, Pleno by combined analysis of growing seasons (2013/ 14- and 2014/ 15).

\begin{tabular}{|c|c|c|c|c|c|c|}
\hline $\begin{array}{l}\text { Planting } \\
\text { dates }\end{array}$ & $\begin{array}{l}\text { Number of } \\
\text { galls root } \\
\text { system }^{-1} \\
\text { (N.G) }\end{array}$ & $\begin{array}{c}\text { Number of } \\
\text { eggmasses } \\
\text { root } \\
\text { system }^{-1} \\
\text { (N.E.M) } \\
\end{array}$ & $\begin{array}{c}\text { Number of } \\
\text { developmental } \\
\text { stages root } \\
\text { system }{ }^{-1} \\
\text { (N.D.S) } \\
\end{array}$ & $\begin{array}{c}\text { Number of } \\
\text { juveniles in } \\
\text { soil } \\
\left(\mathbf{J}_{2 s}\right)\end{array}$ & $\begin{array}{c}\text { Number of } \\
\text { final } \\
\text { population } \\
\left(\mathbf{P}_{\mathbf{f}}\right)\end{array}$ & $\begin{array}{c}\text { Reproduction } \\
\text { factor } \\
\text { (R.F) }\end{array}$ \\
\hline 25 Aug. & $\begin{array}{c}74.17 b \\
(26.07 \%)^{*}\end{array}$ & $150.67 a$ & 331.83a & $6726.90 a$ & $7209.40 \mathrm{a}$ & $4.26 \mathrm{a}$ \\
\hline 25 Sep. & $100.33 a$ & $\begin{array}{c}\text { 99.67b } \\
(33.85 \%)\end{array}$ & $\begin{array}{c}287.17 a \\
(13.64 \%)\end{array}$ & $\begin{array}{l}2404.66 b \\
(64.25 \%)\end{array}$ & $\begin{array}{l}2791.49 b \\
(61.30 \%)\end{array}$ & $\begin{array}{c}2.16 b \\
(49.30 \%)\end{array}$ \\
\hline 25 Oct. & $\begin{array}{c}\text { 97.33a } \\
(2.99 \%)\end{array}$ & $\begin{array}{c}\text { 97.50b } \\
(35.29 \%)\end{array}$ & $\begin{array}{c}116.67 b \\
(64.84 \%)\end{array}$ & $\begin{array}{l}1465.50 \mathrm{c} \\
(78.21 \%)\end{array}$ & $\begin{array}{c}1679.67 \mathrm{c} \\
(76.70 \%)\end{array}$ & $\begin{array}{c}2.05 b \\
(51.88 \%)\end{array}$ \\
\hline LS.D 0.05 & 8.47 & 38.99 & 72.89 & 811.75 & 846.11 & 0.87 \\
\hline
\end{tabular}

*Relative reduction percent to the highest value.

\section{I-5- Number of final population $\left(P_{f}\right)$ :}

Also, the final population $\left(\mathrm{P}_{\mathrm{f}}\right)$ tended to be decreased as intervals advanced in planting dates. The highest value of $\mathrm{P}_{\mathrm{f}}$ was recorded with the $1^{\text {st }}$ planting date (7209.4) followed by the $2^{\text {nd }}$ date $(2791.49)$ and $3^{\text {rd }}$ one (1679.67). There were significant differences among them. The relative reduction percentages of $P_{f}$ between the $1^{\text {st }}$ planting date and the $2^{\text {nd }}$ or the $3^{\text {rd }}$ one was 61.30 or $76.70 \%$, respectively (Table, 1).

\section{1-6- Reproduction factor (R.F):}

Data in Table (1) emphasized reproduction factor (R.F) of root- knot nematode species under stress of three planting dates. The highest effective planting date on R.F was the $3^{\text {rd }}$ planting date (2.05), while the least effective date was the $1^{\text {st }}$ one (4.26). In regard to the relative reduction percentage between the $1^{\text {st }}$ and other applied dates, the $3^{\text {rd }}$ date $(51.88 \%)$ recorded higher reduction than the $2^{\text {nd }}$ one $(49.30 \%)$. Raw data of R.F clarified that the first planting date significantly increased R.F value than the other two planting dates. The $1^{\text {st }}$ planting date achieved double value of the $2^{\text {nd }}$ and the $3^{\text {rd }}$ ones. Where, R.F value was more than four (4.26) in the $1^{\text {st }}$ planting date, and was around 2 for other applied planting dates.

Therefore, all nematode parameters decreased as planting dates were delayed except for $\mathrm{G}$ root system ${ }^{-1}$.

Generally speaking, careful view of data indicated that the $1^{\text {st }}$ planting date $\left(25^{\text {th }}\right.$ August) recorded the highest parameters of root- knot nematodes infection 
(i.e. E.M, D.S, $\mathrm{J}_{2}, \mathrm{P}_{\mathrm{f}}$ and R.F), followed by the $2^{\text {nd }}$ planting $\left(25^{\text {th }}\right.$ September). However, the $3^{\text {rd }}$ planting date $\left(25^{\text {th }}\right.$ October $)$ achieved the lowest values of those parameters.

Our findings are in harmony with those recorded throughout the research work of Gohar (2003), Maareg et al (2004) and Farahat et al (2008) on fluctuation of the root- knot nematodes, $M$. incognita and $M$. javanica populations in sandy soil at AlBostan and West Nubaryia regions. It was obvious that the soil population increased gradually through early Spring season (Feb.- May) and peaked at July and August when soil temperature $>25^{\circ} \mathrm{c}$. In Summer season (July and August), soil population almost remained stable forming one peak during the year. Thereafter, when soil temperature decreased, fast break down in the numbers of juveniles (Js) was observed at early Autumn season (September). Thenceforth, the juveniles population continued to decrease during Winter season to reach the lowest values in December and January (mid Winter). It could be accordingly concluded that the root- knot nematode juveniles peaked once a year in the Nubaryia sandy soil correlating to soil temperature. However, no correlation between soil moisture and nematodes population in soil could be observed, especially, variations in soil humidity along the year were not quite enough $( \pm 5 \%)$ due to the drip irrigation system applied in the areas.

In addition, Maareg, et al (2016) reported that population of root- knot nematodes, $M$. javanica and
M. incognita on sugar beet fields increased with increasing thermal time. The earliest planted beets in August showed the highest juveniles in soil, different stages root system $^{-1}$ and final population numbers as well as reproduction factor. The lowest values of these nematode parameters were achieved when beets were planted in mid- December. Values of nematode parameters were variable. There were remarkable differences between planting dates in nematode population parameters on sugar beet crops.

Eventually, the population of root- knot nematodes is positively correlated to the soil temperature. The highest values of nematode populations were recorded during Summer, while the lowest were recorded in the Winter seasons. Also, Westerdahl et al (2014) recoded that planting sugar beet when soil temperature is below $17^{\circ} \mathrm{c}$ reduced damage and slows down the nematode population build up. From obtained data, all nematode parameters decreased as planting dates were delayed except for $G$ root system ${ }^{-1}$. The $G$ root system $^{-1}$ is not an essential or reliable factor in assessing the damage since most researchers could not distinguish and watch the merged galls (Maareg and Hassnen, 1999).

II- Effect of selected planting dates on yield and yield components of sugarbeet crop:

Table (3) elucidated the effect of tested planting dates on roots, top, biological and sugar yields as well as sucrose and purity percentages of Pleno sugarbeet variety.

Table 3. Effect of selected planting dates on yield and yield components of sugarbeet variety, Pleno by combined analysis of growing seasons (2013/ 14- and 201415).

\begin{tabular}{|c|c|c|c|c|c|c|}
\hline $\begin{array}{c}\text { Planting } \\
\text { dates }\end{array}$ & $\begin{array}{l}\text { Roots yield } \\
\left.\text { (tons fed }^{-1}\right)\end{array}$ & $\begin{array}{l}\text { Top yield } \\
\left.\text { (tons fed }^{-1}\right)\end{array}$ & $\begin{array}{c}\text { Biological yield } \\
\left.\text { (tons fed }^{-1}\right)\end{array}$ & $\begin{array}{l}\text { Sugar yield } \\
\left.\text { (tons fed }^{-1}\right)\end{array}$ & $\begin{array}{c}\text { Sucrose } \\
\%\end{array}$ & $\begin{array}{c}\text { Purity } \\
\%\end{array}$ \\
\hline 25 Aug. & $\begin{array}{c}8.93 b \\
(22.82 \%)^{*}\end{array}$ & $\begin{array}{c}4.82 \mathrm{a} \\
(3.21 \%)\end{array}$ & $\begin{array}{c}13.74 b \\
(16.98 \%)\end{array}$ & $\begin{array}{c}1.63 \\
(11.89 \%)\end{array}$ & $18.22 \mathrm{a}$ & 81.15a \\
\hline 25 Sep. & $\begin{array}{c}10.01 b \\
(13.48 \%)\end{array}$ & $\begin{array}{c}2.92 b \\
(41.37 \%)\end{array}$ & $\begin{array}{c}12.93 b \\
(21.87 \%)\end{array}$ & $\begin{array}{c}1.56 \\
(15.68 \%)\end{array}$ & $\begin{array}{c}15.56 b \\
(14.60 \%)\end{array}$ & $\begin{array}{c}70.63 b \\
(12.96 \%)\end{array}$ \\
\hline 25 Oct. & $11.57 \mathbf{a}$ & 4.98a & $16.55 \mathrm{a}$ & 1.85 & $\begin{array}{c}15.97 b \\
(12.13 \%)\end{array}$ & $\begin{array}{c}72.68 b \\
(10.44 \%)\end{array}$ \\
\hline L.S.D 0.05 & 1.15 & 1.23 & 1.51 & N.S & 2.18 & 6.22 \\
\hline
\end{tabular}

*Relative reduction percent to the highest value.

\section{II-1- Roots yield (tons fed ${ }^{-1}$ ):}

The $3^{\text {rd }}$ planting date (11.57 tons fed $\left.^{-1}\right)$ significantly increased the roots yield than the $1^{\text {st }}(8.93$ tons $\mathrm{fed}^{-1}$ ) and $2^{\text {nd }}$ (10.01 tons fed $^{-1}$ ) planting dates. Where, this planting date increased the roots yield by $22.82 \%$ than the $1^{\text {st }}$ one and by $13.48 \%$ than the $2^{\text {nd }}$ one as shown in Table (3).

\section{II-2- Top yield (tons fed ${ }^{-1}$ ):}

The $2^{\text {nd }}$ planting date (2.92 tons fed $\left.^{-1}\right)$ significantly decreased the top yield than both the $1^{\text {st }}$ $\left(4.82\right.$ tons $\left.\mathrm{fed}^{-1}\right)$ and $3^{\text {rd }}\left(4.95\right.$ tons $\left.\mathrm{fed}^{-1}\right)$ ones. The heavier top yield was recorded during the $3^{\text {rd }}$ planting date followed by $2^{\text {nd }}$ one, without significant differences between them. The top yield of $3^{\text {rd }}$ planting date increased by $41.37 \%$ more than the $2^{\text {nd }}$ one. However, this value was only $3.21 \%$ than the $1^{\text {st }}$ (Table 3).

\section{II-3- Biological yield (tons fed $^{-1}$ ):}

As compared with the planting dates, the $3^{\text {rd }}$ planting date achieved the highest biological yield (16.55 tons $\mathrm{fed}^{-1}$ ) with significant differences followed by the $1^{\text {st }}\left(13.74\right.$ tons fed $\left.{ }^{-1}\right)$ and the $2^{\text {nd }}(12.92$ tons $\mathrm{fed}^{-1}$ ) ones, respectively. The biological yield of the $3^{\text {rd }}$ planting date was increased by $16.98 \%$ more than $1^{\text {st }}$ date and by $21.87 \%$ for the $2^{\text {nd }}$ one. 


\section{II-4- Sugar yield (tons fed ${ }^{-1}$ ):}

The $3^{\text {rd }}$ planting date recorded the highest sugar yield $\left(1.85\right.$ tons fed $\left.^{-1}\right)$ followed by the $1^{\text {st }}$ and $2^{\text {nd }}$ planting dates with an average of 1.63 and 1.56 tons $\mathrm{fed}^{-1}$, respectively, with no significant differences among them. The $3^{\text {rd }}$ planting date significantly produced more sugar yield than the $1^{\text {st }}$ and $2^{\text {nd }}$ ones by 11.89 and $15.68 \%$, respectively (Table, 3 ).

\section{II-5- Sucrose percentage:}

The $1^{\text {st }}$ planting date gave the highest value $(18.22 \%)$ of sucrose \% and significantly increased in sucrose content than the $2^{\text {nd }}(15.56 \%)$ and $3^{\text {rd }}$ $(15.97 \%)$ planting dates. The $1^{\text {st }}$ planting date achieved more sucrose content by 12.96 and $10.44 \%$ than the $2^{\text {nd }}$ and $3^{\text {rd }}$ ones, respectively.

\section{II-6- Juice purity percentage:}

Also, the $1^{\text {st }}$ planting date had the highest value of purity $\%$ and significantly increased than the $2^{\text {nd }}$ and $3^{\text {rd }}$ dates by 12.96 and $10.44 \%$, respectively (Table, 2 ).

Briefly, the presented data revealed that the first planting date recorded only the highest sucrose and purity $\%$ values. However, the $3^{\text {rd }}$ planting date achieved the highest values of roots, top, biological and sugar yield. Therefore, the $3^{\text {rd }}$ planting date was more suitable for planting sugar beet.

The previous data of yield and yield components suggest that the $3^{\text {rd }}$ planting data (during October) significantly increased values of roots, top, biological and sugar yields than both $1^{\text {st }}$ and $2^{\text {nd }}$ planting dates (during Aug. and Sep.).Similar results were stated by Abdou (2000), Abou- Salama and El- Sayed (2002), Agami (2005), El- Agamy et al. (2007) and Maareg et al (2016) reported that the maximum average of roots, top, biological and sugar yields ton $\mathrm{fed}^{-1}$ were achieved when sugarbeet planted during October. The increase in yield and yield components with October planting might be due to the suitable weather conditions especially temperature during plant duration from planting to harvest that helped in formation of strong canopy. Moreover, the increase in length, perimeter and fresh weight of root, leaves fresh weight per plant and sucrose percentage could be the reason for more roots yield, top yield, biological yield and sugar yield tons $\mathrm{fed}^{-1}$.

The results of technological quality declared that the $1^{\text {st }}$ planting date (during August) increased sucrose and purity percentages. On the contrary, El- Agamy et al. (2007) reported that the earlier planting of sugarbeet during August decreased sucrose percentage and quality index. On the other hand, Abdou (2000), Abou- Salama and El- Sayed (2002), Agami (2005) and El- Agamy et al. (2007) indicated that planting of sugabeet during September achieved the highest value of sucrose and purity\%.

\section{Conclusion:}

- The $3^{\text {rd }}$ planting date significantly decreased parameters of nematode infection (i.e. E.M., G.,.D.S.,
$\mathrm{J}_{2}, \mathrm{P}_{\mathrm{f}}$ and R.F) and significantly increased values of root, top, biological and sugar yields. Therefore, this date is recommended as a suitable time for planting sugar beet.

\section{Referencies}

Abd El- Massih, M. I. (1985). Biological studies on major plant parasitic nematode infecting sugar beet in Egypt. Ph.D. Thesis, Fac. of Agric., Cairo Univ., 90 pp.

Abdou, M. A. E. (2000). Effect of planting dates, plant population and nitrogen fertilization on sugar beet productivity under the newly reclaimed sandy soils. Ph. D. Thesis, Fac. of Agric., Mansoura Univ. Egypt.

Abou- Salama, A. M. and El- Syiad, S. I. (2002). Studies on some sugarbeet cultivars under Middle Egypt conditions. i. Response to planting and harvesting dates. Assiut journal of Agricultural Sciences. 31(1): 137-159.

Agami, K. M. (2005). Effect of planting date, plowing depth and nitrogen fertilizer on yield and quality of sugar beet at Noubaria. Ph. D. Thesis. Fa. Of Agric., Moshtohor, Zagazig Univ., Egypt. 188 P.

Barker, K.R. (1985). Nematode extraction and bioassays. Pp. 19-38 in: K.R. Barker, C.C. Carter and J.N. Sasser (eds.). An Advanced Treatise on Meloidogyne. Vol. II. Methodology. North Carolina State Univ. Graphs. Raleigh, N.C.

De Whalley, H. C. S. (1964). Methods of sugar analysis. International commission for uniform methods of sugar analysis. Elsevier Publicating Co., Amesterdam/ London/ New York.

El- Agamy, S. Z.; Abou- salama, A. M.; El- sherief, H. A. and Khater, M. S. H. (2007). Improving of quality for sugar beet varieties using planting and harvesting dates, international conference on "World Perspectives For Sugar Beet and Cane as a Food and Energy Crop, Sharm El- Sheikh, Egypt. P12.

Farahat, A. A; Hendy, H. H; El- Naggar, H. I. and El- Ghonaimy, A. M. (2008). Occurrence and population dynamices of the root- knot nematodes in peach farms with emphasis on sandy soil. Egypt, J. Agronematol., 6 (2): 147- 158.

Gaaboub, I. A., El-Aswad, A., Halawaa, S. and Enas M. Khamis (2005) Feeding deterrent and growth inhibitory properties of Neotorularia aculeolata against the cotton leafworm, Spodoptera littoralis (Boisd.). Egypt. J. Agric. Res. 83 (3), 973-986.

Gaaboub, I. A., Halawaa, S. and Rabiha, A. (2012) Toxicity and Biological Effects of Some Insecticides, IGRs and Jojoba oil on Cotton Leafworm Spodoptera littoralis (Boisd.) Journal of Applied Sciences Research, (2): 131-139. ISSN 1819-544X

Gohar, I. M. A. (2003). The relationships between plant parasitic nematodes of sugarbeet and other 
soil fauna. Ph.D. Thesis, Fac. Of Agric. Moshtohor, Zagazig Univ., Egypt, 221p.

Gohar, I. M. A. and Maareg, M. F. (2005). Relationship between crop losses and initial population densities of root-knot nematode, Meloidogyne in soil of sugarbeet grown in West Nubariya district. Egypt. J. Agric. Res. 83 (4): 1315-1328.

Gohar, I. M. A.; Abd El- razek, A. M.; Abo ElFtooh, A. A.; Abd-El-Rahman, M. M. and Agami, K. M. (2012). The influence of some sugarbeet varieties and nematode, Ethoprop (MOCAP) on the root knot nematode-fusarium disease complex at Ismailia and Nubaria regions. Minufia J. Agric. Res., 376(1):1409-14270.

Ibrahim, I. K. A. (1982). Species and races of rootknot nematodes and their relationships to economic host plants in Northern Egypt. In: Proceedings of the third Research and Planting Conference on Roo- Knot Nematode, Meloidogyne spp. September 13- 17, Conmbra, Portugal, 66- 84.

Ismail, A. E.; Aboul Eid, H. Z. and Besheit, S. Y. (1996). Effects of Meloidogyne incognita on growth response and technological characters of certain sugarbeet varieties. Afro-Asian Journal of Nematology, 6(2): 195-202.

Maareg, M. F.; El- Deeb, M. H. and Ebieda, A. M. (1988a). Susceptibility of ten sugarbeet cultivars to root-knot nematode, Meloidogyne spp. Alexandria Science Exchange, 9 (3): 293- 302.

Maareg, M. F.; El- Gindi, A. Y.; Elsgalaby Mona M. E. and Yassin, Abeer S. (2009). Evaluation of certain sugarbeet varieties for their productivity and susceptibility to Meloidogyne Javanica rootknot nematode.J.Agric.Sci.Mansoura Univ., 34(6):6851-6861.

Maareg M. F.; Gohar, I. M. A. and Abdel Aal, A. M. (2005). Susceptibility of twenty of sugarbeet varieties to the root- knot nematode, Meloidogyne incognita at West Nubariya District. Egypt. J. Agric. Res., 83 (2):789-801.

Maareg, M. F.; Gohar, I. M. A. and Agami, K. M. (2004). Occurrence and population dynamices of the root- knot nematodes, Meloidogyne spp. In sandy soil at Al- Bostan region. In: The effects of nematode on sugarbeet at Al- Bostan and West Nubaryia regions. Project funded from National Council of Sugar Crops (NCSC). 67 pp.

Maareg, M. F.; Gohar, I. M. A. and Agami, K. M. (2016). Effects of selected planting dates on rootknot nematodes and the yield components of some sugarbeet varieties in sandy soil. Egypt, J. Agronematol. Under paplication.

Maareg, M. F. and Hassanein, M. A. (1999). Survey and ecological studies on plant parasitic nematodes in the West Nubaryia. In: The effects of nematode on sugarbeet at Al- Bostan region. Project funded from National Council of Sugar Crops (NCSC). 51 pp.

Maareg, M. F.; Hassanein, M. A.; Allam, A. I. and Oteifa, B. A. (1998). Susceptibilty of twenty-six sugarbeet varieties to root-knot nematodes, Meloidogyne spp. in the newly reclaimed sandy soils of Al- Bostan region. Egyptian Journal of Agronematology, 2 (1): 11- 125.

Maareg, M. F.; Hassanein, M. A. and Ebieda, A. M. (1988 b). Diseases of sugarbeet (Beta vulgaris L.) in Egypt. Aom. \& Dev. Res., 22: 65- 73.

McIntosh, M.S. (1983). Analysis of combined experiments. Agron. J. 75:153-155. doi: 10.2134/agronj1983.00021962007500010041x

Oteifa, B. A. and El- Gindi, D. M. (1982). Relative susceptibility of certain commercially important cultivars to existing biotypes of Meloidogyne incognita and M. Javanica in Nile- Delta, Egypt. In: Proceeding of the $3^{\text {rd }}$ Research and Planting Conf. of Root- Knot Nematode Meloidogyne spp. 13- 17 September Coimbra, Portugal. 66- 84.

Pal, K. and Mcspadden, B. (2006). Biological control of plant pathogens. http://www.apset.org/topics/Documents/PHIBiological control. Pdf. Accessed 6/5/2012.

Steel, R.G.D. and J.H. Torrie, 1980. Principles and Procedures of Statistics: A Biomaterical Approach. Mc Graw Hill Inc; New York, USA.

Westerdahl, B. B.; Becker, J. O. and Kodira, U. C. (2014). Management guide line for nematodes on sugar beet. Agriculture and Natural Resources, University of California .integrated pest management program; April, 25, 2014. 


\section{تأثثر بعض مواعيد الزراعة على نيماتودا تعقد الجذور وإنتاجية محصول بنجر السكر الصنف بلينو}

، أ.د/ جاد حمادة حسن راضى، أ.د/ ابراهيم عبدالله جعبوب، أ.د/ ابراهيم محمد عبده جوهر , د/ حازم محمد عليوه, /تامر فتحى يونس

تتاول هذا البحث دراسة تاثير ثلاث مواعيد لزراعة بنجر السكر (25 أغطس، 25 سبتمبر، 25 أكتوبر ) كأحد الطرق الزراعية فى الغ

مقاومة نيماتودا تعقد الجذور (M. incognita and M. javanica) السائدة فى منطقة الدراسة) وأثر ذلك على محصول بنجر السكر الصنف بلينو فى أراضى رملية ملوثة طبيعيا بهذه النيماتودا تحت نظام الرى بالتنقيط.

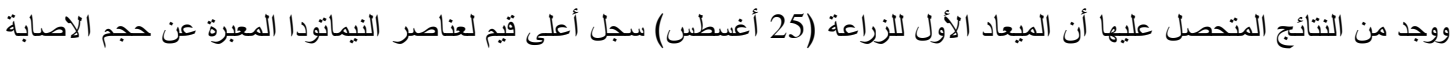

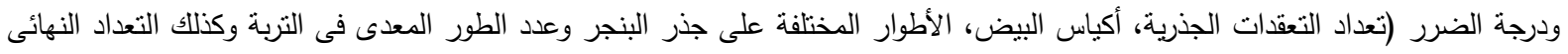

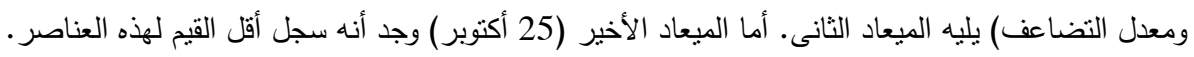
كما وجد أن الميعاد الأول سجل فقط أعلى قيم لنسبة كل من السكروز والنقاوة لبنجر السكر - أما الميعاد الأخير فقد سجل أعلى قيم

لمحصول الجذور ومحصول العرش والمحصول البيولوجى ومحصول السكر (طن/ فدان). لذا يعتبر الميعاد الأخير (25 أكتوبر) أنسب وأفضل المواعيد لزراعة هذا المحصول (الصنف بلينو ) فى منل هذه الأراضى الرملية الملوثة

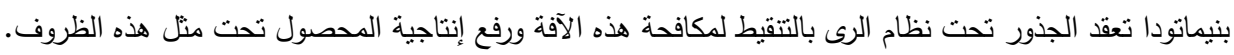

